\title{
Nabywanie języka i umiejętności komunikacyjnych przez dziecko z uszkodzonym narządem słuchu w terapii audytywno-werbalnej. Studium przypadku
}

\section{Purchasing linguistic and communications sill by the child with hearing impairment in auditory-verbal therapy. A case study}

\author{
Anna Barej ${ }^{1,2}$, Agnieszka Pankowska ${ }^{1,2}$ \\ ${ }^{1}$ Instytut Fizjologii i Patologii Słuchu, ul. Zgrupowania AK „Kampinos” 1, 01-943 Warszawa \\ ${ }^{2}$ Światowe Centrum Słuchu, ul. Mokra 17, Kajetany, 05-830 Nadarzyn \\ Adres autora: Anna Barej, Instytut Fizjologii i Patologii Słuchu, ul. Zgrupowania AK „Kampinos” 1, \\ 01-943 Warszawa, a.barej@ifps.org.pl
}

\begin{abstract}
Streszczenie
W artykule zaprezentowano przypadek dziecka z prelingwalnym głębokim uszkodzeniem narządu słuchu rehabilitowanego metodą audytywno-werbalną. Szczegółowej analizie i ocenie została poddana sprawność językowa i komunikacyjna opisanego dziecka po dwóch latach rehabilitacji metodą audytywno-werbalną. Oprócz obserwacji wykorzystano ankietę opracowaną w Instytucie Fizjologii i Patologii Słuchu stworzoną do oceny postępów słuchowych, językowych, poznawczych i komunikacyjnych dziecka rehabilitowanego metodą audytywno- werbalną. Ankietę wypełniają rodzice raz w miesiącu. Wykorzystano również kartę badania logopedycznego z materiałami pomocniczymi „Sprawdź jak mówię” dr Elżbiety Stecko.
\end{abstract}

Dzięki badaniu metodą studium przypadku stworzono obraz rozwoju mowy, nabywania sprawności językowych i komunikacyjnych dziecka z uszkodzonym narządem słuchu rehabilitowanego metodą audytywno-werbalną.

słowa kluczowe: uszkodzenie narządu słuchu • terapia audytywno-werbalna • sprawności językowe • sprawności komunikacyjne

Abstract

The article described the study case of a child with an profound prelingual hearing loss rehabilitated with an auditory-verbal therapy (AVT). The linguistic efficiency and communications of the child after two years rehabilitation applying auditory-verbal method was subjected to a detailed analysis. Apart from observation a questionnaire elaborated in the Institute of Physiology and Pathology of Hearing was used for evaluation of auditory, linguistic, cognitive and communication development of the rehabilitated child. The questionnaire form have been filled in by parents once a month. Additionally a card of the speech-therapy examination with auxiliary materials "Check how I am speaking" by Dr. Elżbieta Stecko was used in this case.

Thanks to the case study it was possible to deliver an image of speech, linguistic and communicative abilities development in case of a hearing impaired child rehabilitated with the auditory-verbal therapy.

Key words: hearing impairment $\bullet$ linguistic skills $\bullet$ communication skills $\bullet$ auditory-verbal therapy

\section{Wstęp}

Nieprzerwane dyskusje na temat tego jaka metoda rehabilitacji dziecka $\mathrm{z}$ wadą słuchu jest najkorzystniejsza toczą się od wielu lat. Głównym punktem tych dyskusji jest pytanie o udział drogi wzrokowej w nauce mowy dziecka z uszkodzonym narządem słuchu. Metoda audytywno-werbalna opiera się na nauczaniu mowy na drodze słuchowej, bez odczytywania mowy z ust i bez nauki języka migowego. W swoim założeniu metoda promuje wczesne wykrycie i zdiagnozowanie wady słuchu, a w ślad za tym zastosowanie nowoczesnej technologii czyli właściwie dobranego urządzenia wspomagającego słyszenie. Wczesne wykrycie wady słuchu, zaopatrzenie w odpowiednie urządzenie ma na celu stymulację odpowiednich struktur mózgu dziecka, będących w fazie dojrzewania, poddanie ich działaniu 
intensywnych bodźców odpowiedzialnych za prawidłowy rozwój słyszenia, tak, aby w przyszłości te struktury wypełniały przypisane im funkcje. Metoda zakłada aktywny udział rodziców w procesie rehabilitacji. Rodzice nie tylko są obecni podczas sesji terapeutycznych, ale też aktywnie w nich uczestniczą ucząc się odpowiednich technik i strategii postępowania, które stosują $\mathrm{w}$ domu w codziennym obcowaniu $\mathrm{z}$ dzieckiem. W porównaniu $\mathrm{z}$ innymi programami wczesnej rehabilitacji terapia audytywno-werbalna wymaga więc większego zaangażowania nie tylko od terapeuty, lecz także od rodziców i dzieci.

\section{Studium przypadku chłopca $\mathrm{z}$ obustronnym niedosłuchem typu odbiorczego prowadzonego metodą audytywno-werbalną}

Dane socjodemograficzne chłopca i jego rodziny

Badany chłopiec (obecnie 3 lata i 1 miesiąc) jest dzieckiem słyszących rodziców. Ma starszą prawidłowo rozwijającą się siostrę (7 lat) i prawidłowo rozwijającego się brata bliźniaka. Rodzice dziecka mają wyższe wykształcenie i obecnie pracują zawodowo.

\section{Etiologia uszkodzenia słuchu}

Etiologia uszkodzenia słuchu badanego chłopca jest nieznana. Z przeprowadzonego wywiadu wynika, że ciąża bliźniacza przebiegała prawidłowo. Poród nastąpił o czasie siłami natury, chłopiec urodził się drugi. Po porodzie stan chłopca oceniono na dobry (10 punktów w skali Apgar). Wywiad rodzinny nieobciążony. Badania genetyczne wykluczyły uszkodzenie słuchu o podłożu genetycznym. Istnieje podejrzenie wrodzonego zakażenia wirusem cytomegalii.

Zdiagnozowanie wady słuchu i zaopatrzenie w protezy słuchowe

Badanie przesiewowe przeprowadzone w szpitalu po urodzeniu dziecka zrodziło podejrzenie wystąpienia wady słuchu. Rodzice bardzo szybko podjęli działania w celu dokładnej diagnozy uszkodzenia słuchu chłopca. W piątym miesiącu życia dziecka, wykonano audiometrię odpowiedzi elektrycznych z pnia mózgu (BERA). Badanie wykazało niedosłuch w granicach $90 \mathrm{~dB}$. W szóstym miesiącu życia dziecka wykonano ponowne badanie, które potwierdziło obustronny niedosłuch typu odbiorczego na poziomie 90-100 dB.

Po wykonaniu pierwszego badania chłopiec otrzymał aparaty słuchowe Oticon Sumo DM, które szybko zaakceptował. Korzystał z nich systematycznie.

W ósmym miesiącu życia, chłopiec został zakwalifikowany do operacji wszczepienia systemu implantu ślimakowego. Operacja odbyła się w dziesiątym miesiącu życia dziecka. Chłopcu został wszczepiony implant ślimakowy Nucleus Freedom do ucha lewego. Decyzja została podjęta na podstawie wywiadu z mamą, według której chłopiec zdradzał symptomy leworęczności, mama chłopca jest również osobą leworęczną. Podejrzenia mamy potwierdziły się w późniejszym okresie rozwoju chłopca.

Miesiąc po wszczepieniu systemu implantu ślimakowego nastąpiło podłączenie procesora mowy.
Od momentu zaopatrzenia chłopca w aparaty słuchowe rodzice uczestniczyli $\mathrm{w}$ programie rehabilitacji w wybranym ośrodku. Z wywiadu z mamą wynika, że w aparatach słuchowych chłopiec sporadycznie reagował na dźwięki otoczenia.

Na terapię metodą audytywno-werbalna prowadzoną w Instytucie Fizjologii i Patologii Słuchu rodzice zgłosili się $\mathrm{z}$ chłopcem dwa miesiące po podłączeniu procesora mowy. Do takiego wyboru przyczyniła się zmiana miejsca zamieszkania i bliskość Instytutu.

\section{Przebieg procesu rehabilitacji}

Zakładając aktywny udział rodziców w terapii, metoda audytywno-werbalna wymaga przygotowania rodziców do tej roli. Zgodnie $\mathrm{z}$ wytycznymi metody to rodzice pozostają „klientami” terapeuty.

Przygotowując sesje terapeuta opracowuje cele zajęć z zakresu słyszenia, mowy, języka, umiejętności poznawczych i komunikacyjnych, dzięki temu ma możliwość systematycznego monitorowania postępów dziecka, co sprawia, że każda sesja staje się diagnostyczna. Angażując czynnie rodziców, terapeuta przygotowuje również ich do systematycznego monitorowania postępów dziecka. Określając cele zajęć, które są przedstawiane rodzicom terapeuta wyjaśnia ich znaczenie dla rozwoju języka i komunikacji. Dzięki temu rodzice widzą zasadność podejmowanych działań. Terapia opiera się więc nie tylko na zaufaniu jakim rodzice darzą terapeutów, ale na przekonaniu o słuszności danych ćwiczeń i zalecanego postępowania. Rodzice wypełniają raz w miesiącu ankietę "Informacja na temat zmian w zachowaniu dziecka” na podstawie zaobserwowanych postępów dziecka, odnotowując obserwację z zakresu rozwoju słyszenia, mowy, języka, umiejętności poznawczych i komunikacyjnych (Rycina 1).

Analiza ankiet wypełnionych przez mamę chłopca po miesiącu, po trzech, sześciu, dziewięciu miesiącach (Tabela 1) daje obraz harmonijnego rozwoju słuchania, mowy, języka, umiejętności poznawczych. Zestawione informacje $\mathrm{z}$ ankiet $\mathrm{z}$ pierwszego roku rehabilitacji przedstawia Tabela 1 .

Ankietę rodzice wypełniają do pojawienia się w mowie czynnej pacjenta prostego zdania. W tabeli umieszczono oryginalną formę zapisu dokonanego przez mamę. Proporcjonalnie do czasu uczestniczenia w terapii, mama chłopca doskonaliła umiejętność obserwacji postępów dziecka.

W drugim roku terapii przyrost leksykalny nastąpił bardzo szybko i rzeczą niemożliwą stało się zarejestrowanie wszystkich pojawiających się słów.

Nabywanie umiejętności językowych i komunikacyjnych

Drugi rok użytkowania systemu implantu ślimakowego i ukierunkowanej terapii przyniósł intensywny wzrost słownika biernego i czynnego u badanego dziecka. System językowy rozwijał się skokowo.

Analiza systemu fonologicznego przeprowadzona na podstawie karty badania logopedycznego „Sprawdź jak mówię" dr Elżbiety Stecko dla dzieci poniżej 7 roku życia, 


\begin{tabular}{|c|}
\hline INFORMACJA NA TEMAT ZMIAN W ZACHOWANIU DZIECKA \\
\hline 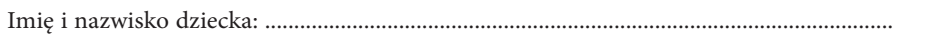 \\
\hline Wiek rozwojowy: ................... Wiek słuchowy (miesiące korzystania z implantu): .............. \\
\hline $\begin{array}{l}\text { Instrukcja: Wypelniamy wszystkie wymienione obszary aktywności. Opisujemy w spoób } \\
\text { bardzo dokładny i podajemy te umiejętności, które dziecko prezentuje powtarzalnie i je- } \\
\text { steśmy pewni tych zachowań. Opisu dokonujemy raz w miesiące. }\end{array}$ \\
\hline PRZED PODŁACCZENIEM PROCESORA MOWY / PO PODŁĄCZENIU PROCESORA MOWY \\
\hline Słuchanie: co słyszy moje dziecko, tzn. na jakie dźwięki reaguje, warunek nie widzi żródła sygnału. \\
\hline Mowa: jakie dźwięki wydaje dziecko? \\
\hline Język: co rozumie dziecko, kiedy do niego mówimy? \\
\hline Umiejętności poznawcze: wszystko, co dziecko potrafi (siedzi, chodzi, manipuluje przedmiotami itp. \\
\hline Komunikacja: jak porozumiewa się z nami (np. gestem, krzykiem, płaczem itp.) \\
\hline
\end{tabular}

Rycina 1. Ankieta „Informacja na temat zmian w zachowaniu dziecka" pozwoliła zaobserwować substytucje w obrębie głosek $\check{s} \check{z}$ (zastępowane głoskami $s z$ ) Głoska $r$ przeważnie realizowana jest jako $r l$ (głoska jednouderzeniowa, przedniojęzykowo- dziąsłowa, dźwięczna $r l y b a$ ). Obok tej realizacji pojawiają się jeszcze substytucje $r$ głoskami półotwartymi (okulary - okulaly). Chłopiec obecnie doskonali wymowę głosek $s, z$. Nie posiada samogłosek nosowych. Artykulacja chłopca pozostaje w normie wiekowej.

Dokonując analizy systemu fonologicznego u dzieci niesłyszących, nie można ograniczyć się do badania artykulacji poszczególnych głosek, ale należy dokonać analizy w odniesieniu do wyników audiometrii wolnego pola. Dzięki temu możemy ocenić czy poziom wzmocnienia pozwala dziecku na prawidłowy odbiór wszystkich częstotliwości.

W drugim roku rehabilitacji w mowie chłopca pojawiły się poszczególne kategorie językowe. Pojawiła się deklinacja rzeczownika. Obecnie prawidłowo realizowana jest większość form przypadkowych w liczbie pojedynczej. Pojawił się wołacz, co jest związane $\mathrm{z}$ wczesnym wzorem, gdyż mama chłopca jest osobą charakteryzującą się staranną wymową i dbałością o czystość języka polskiego, używa wołacza w formach adresatywnych. W liczbie mnogiej prawidłowo używa mianownika, dopełniacza, biernika, narzędnika.

Fleksja czasowników badanego chłopca charakteryzuje się prawidłowym użyciem wszystkich form liczby pojedynczej i mnogiej. Chłopiec prawidłowo używa trybów rozkazującego, oznajmującego i przypuszczającego. W kategorii strony używa form wskazujących na różnicowanie strony czynnej i zwrotnej (myje się, czesze się), pojawia się również wykładnik strony biernej. Chłopiec różnicuje czasy teraźniejszy (Pani gotuje..) przeszły (Pani poszła..) oraz przyszły (Mam kupi...).
$\mathrm{W}$ drugim roku rehabilitacji pojawiły się pierwsze zdania, były one w większości przypadków dwuczłonowe, a czasem ulegały rozbudowie, pojawiały się dopełnienia i okoliczniki. Pod koniec trzeciego roku życia chłopiec zaczął posługiwać się zdaniami pojedynczymi rozwiniętymi, a równocześnie z nimi pojawiły się zdania złożone. Jako pierwsze wśród nich pojawiły się zdania przyczynowe (Założył czapkę, bo jest zimo), co nastąpiło zgodnie z normą rozwoju mowy. Pod koniec trzeciego roku życia chłopiec posługiwał się wszystkimi typami zdań.

Analizując słownik badanego chłopca pod kątem semantycznym możemy określić zakres pojęciowy nazw reprezentujących poszczególne kategorie.

W słowniku chłopca, w grupie rzeczowników do najliczniej reprezentowanych należą: nazwy zwierząt, pojazdów, osób, zabawek, bohaterów bajkowych, pokarmów, ubrań, części ciała, przedmiotów codziennego użytku, przedmiotów związanych z domem, nazwy miejsc i zjawisk przyrodniczych.

W przeprowadzonym badaniu na podstawie materiału logopedycznego dr Elżbiety Stecko, w prezentowanej próbie czterdziestu rzeczowników chłopiec nie nazywa jednego rzeczownika, jest to: fartuszek.

Wśród czasowników jakie znajdują się w słowniku chłopca najwięcej dotyczy ruchu i działania. W przytaczanej już karcie badania logopedycznego, chłopiec określił wszystkie czasowniki, przymiotniki, przysłówki, oraz nazwy pojęć (zwierzęta, ubrania, meble, kwiaty), prawidłowo określił wszystkie badane stosunki przestrzenne.

W grupie przymiotników słownik chłopca jest bardzo bogaty. Jest to efektem charakterystycznego w rozwoju mowy 
Tabela 1. Ankieta „Informacja na temat zmian w zachowaniu dziecka” wypełniana przez matkę chłopca w okresach 1,3,6,9 miesięcy po podłączeniu procesora mowy

\begin{tabular}{|c|c|c|c|c|c|}
\hline & Słuchanie & Mowa & Język & $\begin{array}{l}\text { Umiejętności } \\
\text { poznawcze }\end{array}$ & Komunikacja \\
\hline $\begin{array}{l}1 \text { miesiąc po } \\
\text { podłączeniu } \\
\text { procesora mowy }\end{array}$ & $\begin{array}{l}\text { Reaguje na: } \\
\text { bębenek, kołatkę } \\
\text { cymbałki, pukanie } \\
\text { do drzwi klaskanie, } \\
\text { na głos rodziców, } \\
\text { dzwonek do drzwi }\end{array}$ & & & $\begin{array}{l}\text { Chodzi, sam } \\
\text { schodzi z łóżka }\end{array}$ & Krzykiem, płaczem \\
\hline $\begin{array}{l}3 \text { miesiące po } \\
\text { podłączeniu } \\
\text { procesora mowy }\end{array}$ & $\begin{array}{l}\text { Reaguje na: } \\
\text { zabawki wydające } \\
\text { dźwięk, pieska, } \\
\text { tamburyn, trójkąt, } \\
\text { flet, wydaje się, że } \\
\text { reaguje na głośno } \\
\text { wypowiedziane imię }\end{array}$ & $\begin{array}{l}\text { ble, ble } \\
\text { (coś brzydkiego, } \\
\text { niedobrego) } \\
\text { eee yyy } \\
\text { (jak nie chce czegoś) }\end{array}$ & $\begin{array}{l}\text { Chyba reaguje } \\
\text { na imię, (głośno } \\
\text { wypowiedziane) } \\
\text { reaguje na głoski } \\
\text { o, a }\end{array}$ & $\begin{array}{l}\text { Potrafi zmienić } \\
\text { kierunek, } \\
\text { zatrzymuje się } \\
\text { przed znanymi } \\
\text { przeszkodami, sam } \\
\text { się bawi (włącza } \\
\text { zabawki) wchodzi } \\
\text { do łóżeczka. }\end{array}$ & $\begin{array}{l}\text { Gestem: pokazuje } \\
\text { przedmiot, który chce } \\
\text { i mówi „eee, yyy” }\end{array}$ \\
\hline $\begin{array}{l}6 \text { miesięcy po } \\
\text { podłączeniu } \\
\text { procesora mowy }\end{array}$ & $\begin{array}{l}\text { Reaguje na } \\
\text { dźwięki domowe: } \\
\text { ekspres do } \\
\text { kawy, kuchenkę } \\
\text { mikrofalowa, szelest } \\
\text { workiem foliowym }\end{array}$ & $\begin{array}{l}\text { Naśladuje zwierzęta: } \\
\text { kot, pies, krowa, } \\
\text { kaczka, mysz, koza, } \\
\text { zając, indyk, lew, } \\
\text { próbuje mówić lala- } \\
\text { halo (nalo), mówi: } \\
\text { ma (gdy czegoś } \\
\text { nie ma i rozkłada } \\
\text { raczki), oko (ooo), } \\
\text { mama, am na } \\
\text { jedzenie, mama, } \\
\text { baba, samolot } \\
\text { robi uuu i wyciąga } \\
\text { rączkę do góry, kawa } \\
\text { (wawa) }\end{array}$ & $\begin{array}{l}\text { Reaguje na imię: } \\
\text { odwraca głowę. } \\
\text { Idziemy, zrób pa- } \\
\text { pa- idzie do drzwi } \\
\text { i macha rączką. } \\
\text { Gdzie jest oko, } \\
\text { pokazuje oko. } \\
\text { Gdzie lala pokazuje } \\
\text { lalę, gdzie mama, } \\
\text { pokazuje mamę, } \\
\text { Robimy kawę: } \\
\text { idzie do kuchni } \\
\text { i pokazuje ekspres, } \\
\text { mówi wa- wa, } \\
\text { Nie wolno- } \\
\text { macha wówczas } \\
\text { paluszkiem i mówi } \\
\text { nu- nu }\end{array}$ & $\begin{array}{l}\text { Chodzi pewnie, } \\
\text { biega, wspina się } \\
\text { na fotel i kanapę, } \\
\text { stołki, zamyka } \\
\text { i otwiera drzwi, } \\
\text { ubiera sam czapkę } \\
\text { i szalik i jedną } \\
\text { rękawiczkę, } \\
\text { próbuje się } \\
\text { sam umyć } \\
\text { i posmarować } \\
\text { kremem, buduje } \\
\text { wieże z klocków } \\
\text { (4), bazgrze, } \\
\text { podskakuje, } \\
\text { tańczy, klaszcze, } \\
\text { chodzi na } \\
\text { paluszkach, kopie } \\
\text { piłkę, przesuwa } \\
\text { różne przedmioty, } \\
\text { rzuca piłkę dwoma } \\
\text { rączkami, rzuca } \\
\text { małe przedmioty, } \\
\text { rzuca małe } \\
\text { przedmioty jedną } \\
\text { rączką }\end{array}$ & $\begin{array}{l}\text { Gdy chce pic bierze } \\
\text { butelkę i idzie do } \\
\text { kuchi, staje przy } \\
\text { szafce z sokiem, } \\
\text { „Kłoci się z bratem”- } \\
\text { mówi po swojemu } \\
\text { z niezadowoleniem } \\
\text { i grozi palcem lub } \\
\text { macha rączką. Kiedy } \\
\text { się wstydzi lub boi, } \\
\text { przytula się do mamy } \\
\text { lub taty, Gdy się obrazi } \\
\text { na kogoś biegnie do } \\
\text { innej bliskiej osoby; } \\
\text { żali się, krzyczy, płacze. } \\
\text { Pokazuje, że czegoś } \\
\text { nie ma rozkładając } \\
\text { rączki }\end{array}$ \\
\hline $\begin{array}{l}9 \text { miesiący po } \\
\text { podłączeniu } \\
\text { procesora mowy }\end{array}$ & Reaguje na szept & $\begin{array}{l}\text { Mówi czysto mama, } \\
\text { u-u (sowa), } \\
\text { ooo- (kura) „mmm” } \\
\text { - krowa } \\
\text { „u-u” - małpka } \\
\text { „beee” - owca } \\
\text { „baba” - pokazuje } \\
\text { na ludzi, } \\
\text { „mama” - mama } \\
\text { (nie zawsze) } \\
\text { „ne ma” - czegoś } \\
\text { nie ma, } \\
\text { „jeeee” - coś jest } \\
\text { „ał”- coś go zabolało, } \\
\text { „bławo” - klaszcze } \\
\text { w rączki, } \\
\text { „papa” nie zawsze, } \\
\text { „tamm” - gdy chce } \\
\text { by coś wróciło na } \\
\text { swoje miejsce } \\
\text { „nee” gdy czegoś } \\
\text { nie chce. } \\
\text { Coś sobie tłumaczy, } \\
\text { mówi do siebie, } \\
\text { mówi do nas, } \\
\text { pokazuje }\end{array}$ & $\begin{array}{l}\text { Rozumie pytania: } \\
\text { gdzie jest kot, } \\
\text { pies, małpka, lew } \\
\text { (przynosi dane } \\
\text { zwierzątko i mówi } \\
\text { jakie wydaje } \\
\text { dźwięki) } \\
\text { Pokaże gdzie jest } \\
\text { baba, dziadek, tata,, } \\
\text { Taś (Staś) } \\
\text { Rozumie proste } \\
\text { polecenia: załóż } \\
\text { buty, chodź, }\end{array}$ & $\begin{array}{l}\text { Pomaga } \\
\text { „rozpakowywać” } \\
\text { zmywarkę, } \\
\text { Sam się bawi } \\
\text { i zaczyna oglądać } \\
\text { bajki } \\
\text { Zaczyna oglądać } \\
\text { filmy edukacyjne } \\
\text { dla maluchów } \\
\text { szuka podobnych } \\
\text { przedmiotów } \\
\text { co w filmach } \\
\text { w swoich } \\
\text { zabawkach. } \\
\text { „Wkłada” } \\
\text { przedmioty do } \\
\text { sortera, włącza } \\
\text { komputer, próbuje } \\
\text { się ubrać }\end{array}$ & $\begin{array}{l}\text { Opowiada, używa } \\
\text { onomatopei, opowiada } \\
\text { „po swojemu”, chętnie } \\
\text { kłóci się z bratem }\end{array}$ \\
\hline
\end{tabular}


naśladownictwa. Rodzice chłopca, osoby z wyższym wykształceniem, mówią piękną polszczyzną.

Posługiwanie się językiem na opisanym powyżej poziomie zapewnia dziecku sprawne funkcjonowanie w społeczeństwie. Chłopiec nie tylko potrafi zakomunikować swoje potrzeby, rozumie pytania i udziela adekwatnych odpowiedzi, rozwija swoją wiedzę pytając o interesujące go rzeczy czy zjawiska. Zaczyna używać słów mających zabarwienie emocjonalne, rozwija ekspresję wypowiedzi. Przenosi usłyszane wypowiedzi dorosłych lub bohaterów bajek i używa je adekwatnie do sytuacji, co potwierdza ich rozumienie.

Nowym etapem rozwoju językowego chłopca są pytania. Chłopiec wkroczył w wiek intensywnego poznawania świata i odkrył, że można go poznać zadając pytania. Pojawiło się pytanie dlaczego?

W komunikacji chłopiec dąży do kontaktów z innymi ludźmi, również spoza najbliższego otoczenia. Źródłem nowych doświadczeń komunikacyjnych stało się pójście do przedszkola i wejście w grupę rówieśniczą. Chłopiec potrafi organizować wspólne działanie, zabawę, bierze aktywny udział w zajęciach.

Dziecka potrafi wyrazić i nazwać swój stan emocjonalny, nie tylko związany z konkretną sytuacją, ale również z przeszłością. Zadaje pytania i rozumie odpowiedzi, potrafi odpowiadać na pytania, opowiadać. Potrafi prosić, przepraszać dobierając odpowiednie słowa.

\section{Podsumowanie}

Działania rehabilitacyjne podejmowane w metodzie audytywno-werbalnej mają na celu umożliwienie dziecku czynnego wzrostu i funkcjonowania w zwykłych środowiskach, umożliwić pełne uczestnictwo w życiu społecznym. Myślą przewodnią podejścia audytywno-werbalnego jest wspieranie podstawowego prawa człowieka do rozwoju umiejętności komunikacyjnych w środowisku rodzinnym i grupach społecznych.

Prowadzenie terapii w sposób przemyślany, zorganizowany, celowy, wsparty miłością rodziny i społeczną akceptacją, zakłada uczestnictwo dzieci w klasach szkół powszechnych i pełną komunikację w domu, szkole czy na ulicy.

Podsumowując wyniki badań i obserwacji, można stwierdzić, że głęboki, prelingwalny ubytek słuchu nie jest barierą niemożliwą do pokonania. Jednak, aby tak się stało muszą być spełnione odpowiednie warunki: szybkie wykrycie wady słuchu, zastosowanie odpowiedniej, nowoczesnej technologii wspomagających słyszenie i aktywne zaangażowanie rodziny i otoczenia, które stwarza dziecku korzystne możliwości rozwoju językowego i komunikacyjnego.

Rehabilitacja chłopca zmierzać będzie w kierunku dalszego doskonalenie sprawności językowych i komunikacyjnych.

\section{Piśmiennictwo:}

1. Ciszyńska J., Korendo M.: Wczesna interwencja terapeutyczna. Kraków, 2007

2. Estabrooks W.; Auditory-Verbal, Therapy and Practice. Washington, 2006

3. Löwe A.: Każde dziecko może nauczyć się słuchać i mówić. Poznań, 1999
4. Trochymiuk A.; Sprawności językowe i komunikacyjne w rozwoju mowy dziecka z uszkodzonym narządem słuchu. Studium przypadku. Audiofonologia, 2001; 19: 122-53.

5. Zarębina M.: Kształtowanie się systemu językowego dziecka. Wrocław, 1965 